\title{
Unification 0i Marriage Law And Its Problems
}

\author{
Syahrul \\ Dosen Institut Agama Islam Negeri \\ syahrulhs@gmail.com \\ Evie Syalviana \\ Dosen Institut Agama Islam Negeri \\ evie.syalviana1990@gmail.com
}

\begin{abstract}
Abstrak: Law is a normative rule that govern human behaviors. The development of law as rule is not stagnant in one situation. But, its grew out from the awareness of society that requires the existence of law. Therefore, law always adopts the values that grow in society like; customary law, traditions and religions law. The consequences of laws as social and cultural products, even products of political ideology, making law is always contextual with the reality of society. This article try to understand the unification of marriage law in Indonesia and the problems that arise in the unification process. Unification is process of unify the laws in sociey or unify the national law in society. The article finds that there are many problems arising from the unification of marriage law in Indonesia, especially those related to interfaith marriages. So, it is not surprising that there are so many products of the marriage law probide the interfaith marriage in Indonesia, especially if interfaith marriage involves woman and man Muslims.
\end{abstract}

Keyword: Interfaith Marriage, National Law, Islamic Law

Abstrak: Hukum adalah aturan-aturan normatif yang mengatur pola perilaku manusia. Hukum tidak tumbuh di ruang yang vakum, melainkan tumbuh dari kesadaran masyarakat yang membutuhkan adanya suatu aturan bersama. Karena itu, hukum selalu mengadopsi nilai-nilai yang tumbuh dan berkembang dimasyarakat; nilai-nilai adat, tradisi dan agama. Konsekuensi hukum sebagai produk sosial dan kultural, bahkan juga produk politik yang bernuansa ideologi, menjadikan hukum selalu bersifat kontekstual. Tulisan ini berusaha untuk mengungkap tentang unifikasi hukum perkawinan di Indonesia dan problematika yang muncul pada proses unifikasi tersebut. Unifikasi merupakan penyatuan hukum yang berlaku secara nasional atau 
penyatuan pemberlakuan hukum secara nasional. Penulis menemukan adanya banyak persoalan yang muncul dari unifikasi hukum perkawinan di Indonesia, khususnya yang terkait dengan perkawinan beda agama. Maka, tidak heran jika begitu banyak produk undang-undang perkawinan yang menjadi penghalang terjadinya nikah beda agama di Indonesia, khususnya jika melibatkan orang Islam.

Kata Kunci: Pernikahan Beda Agama, Hukum Nasional, Hukum Islam

\section{A. Introduction}

Law is a normative rule that govern human behaviors. The development of law as rule is not stagnant in one situation. But, its grew out from the awareness of society that requires the existence of law. Therefore, law always adopts the values that grow in society like; customary law, traditions and religions law. The consequences of laws as social and cultural products, even products of political ideology, making law is always contextual with the reality of society. Then, the existence of court is important to run law that was created or established in the community. Indonesia as state law has at least five types of justice. First Judicial Affairs, which is handling to the common cases for all citizens, without distinction of their religions. Second, Religious Court, handling for cases of marriage, divorce, reconciliation, endowments, etc. Third, Constitutional Court. Fourth, State administrative court and the last, Military Court which is deal with cases related to the military ${ }^{1}$.

Indonesia is a country which is categorized as non-secular state and non-religious. Indonesia's legal system is pluralistic. The emergence and enactment of some law has its own style and composition. The style and character of law in Indonesia is always influenced by religious intervention. Although, Indonesia is no n-religious state, but the government requires that people must profess religion that has been set by the State. Since 1965 the entire population of Indonesia is obliged to adhere to one of the 6 formal religions that are recognized by the State; Islam, Protestant, Catholic, Buddhist, Hindu, Confucian. The result of the government regulations in society seems make religious intervention

${ }^{1}$ Muhammad Ishar Helmi, "Penerapan Azas Equality Before The Law dalam Sistem Peradilan Militer”, Jurnal Cita Hukum, Vol. 1, No. 2. Desember 2013. H. 305. 
very strong in formation of the State law. ${ }^{2}$ One of the most prominent is marriage law. The involvement of the religion, especially Islam, is very dominant in the formation of marriage law. Finally, the unification of marriage law made contradictions and unclear purposes in society.

The involvement of religion in formation of marriage laws creates a contradictory in plural society. Because our country formally just recognizes the existence of 6 religions, but when the formation of family law, the dominance of a particular religion (Islam) is very strong. So, the unification of marriage law that is expected to unite all of religious law became a big problem. One side, marriage is indeed can be done by individuals. But, marriage is a ritual that must involve religious institutions. Marriage is a public and personal affair. So, the settings are not solely based on the consideration or religious reasons, but also need to consider personal and public interests (Mulia 2007: 120).

Reformation of family law in Indonesia began in 1950s CE. 1 October 1950 the Minister of Religions Affairs sets up a Committee Investigator in charge of researching again all rules regarding to marriage and marriage drafting which accordance with the times. After that, the government proposed draft laws to the Parliament in 1958. Unfortunately, after that, the Parliament been suspended through a presidential decree of July 5, 1959 and the draft law never heard again. Concrete efforts to reform family law in Indonesia began in the 1960s which was led to the birth of law no. 1 year 1974 about marriage law and become the first law in Indonesia, which regulates marriage nationally and subsequently equipped with the Government Regulation no. 9 of 1975 as guidelines for implementation. But it was effective since October 1, 1975.

Before that, marriage law is regulated through a variety of law, like; Customary Law for the native citizen, Islamic law for the Moslem, Christian Indonesian Marriage Ordinance for the Christians. Book of Civil Law for European which descent from Indonesia and China, and regulations for mixed marriages for mixed marriages. It was obvious that the Marriage Law was the principal goal of unification or

2 Saifuddin, "Prospek Hukum Islam dalam Sistem Hukum Indonesia", AlAdalah, Vol 14, No. 2, 2017, h. 473 - 477. 
uniformity of marriage laws that were previously very diverse. Ideally, as a legal product, Marriage Law needs to be re-examined the extent of its effectiveness in regulating people's behavior in marriage problem. But, after 37 years have passed we never see serious efforts to evaluate how effective the Marriage Law as a source of law and how people respond it as well as irrelevant whether the Marriage Law is still used today (Mulia 2007: 145).

After formulating Marriage Law, the next reformation was marked by the birth of the Compilation of Islamic Law (KHI), which is specifically used for the Islamic. KHI is a collection of Islamic law from new order era whose content is taken from a Books of Jurisprudence which are generally written in the Middle Ages. KHI confirmed as the official guidelines as law material for the judges in religious courts throughout Indonesia under Presidential Instruction no. 1 year 1991.

Marriage Law looked at marriage is not only seen from the purely formal aspect, but also from the aspect of religion. Aspects of religion set about the validity of a marriage, while the formal aspects set about the administrative aspects or marriage documentation. According to the Marriage Law, both of these aspects must be fulfilled. If the marriage took place only in accordance with State Law, regardless of religion, the marriage is considered invalid. Conversely, if the marriage is performed only for the elements of religious law, without considering or ignoring the State Law, then the marriage is considered invalid too.

\section{B. Interiaith Marriage in Islam}

Religions in this world can be classified into monotheism religion; Jewish, Christian, and Islamic and non-monotheism religions; Zoroastrianism, Saba' $i$, indigenous religions, etc. The monotheism religions are classified as scripture religion (Ahl Kitab), while the non-monotheism religion can be classified as polytheistic (Musyrik). However, to see whether non-monotheism religion can be classified to the polytheists or Ahl Kitab, then there is a difference of opinion among scholars in Islam ${ }^{3}$. Imam Shafi'i Experts identify the Ahl Kitab as descent

\footnotetext{
${ }^{3}$ Muhammad Galib. Ahl Kitab; Makna dan Cakupannya. Jakarta. Paramadina.
} 
of Jews and Christians, while Abu Hanifah said that the majority of the Islamic scholars opinion said that anyone who followed the teachings of the Prophet and scripture that God revealed it can categorize as $\mathrm{Ahl}$ Kitab, eventhough they are not from Jews and Christians. Therefore, who is obeying Shuhuf Ibrahim or Zabur, revealed to Prophet Daud, can be categorized as Ahl Kitab.

Interfaith Marriage is marriage between people of different religions. In our country, this marriage has been regulated in Law no. $1 / 1974$, and the Compilation of Islamic Law, even been constituated by Council of Indonesian Ulama (MUI), that the prohibition marriage between a man non-Muslim with a woman Muslim. According to most of Islamic scholars, interfaith marriage are not allowed, unless the woman categorized as Ahl Kitab with the requirements. Term Ahl Kitab refers to the community or group of believers who have the holy books or scripture by Allah to the Prophet and His Messenger.

Islam forbids marriage between a Muslim man with polytheistic women and marriage between polytheistic men with Muslim women, based on the Qur'an. "Do not marry polytheistic women until they believe in one God, actually slave Muslim woman is better than polytheistic women even though she pleases you. Also, do not marry (girl) with polytheistic men until they believe in one God. A Muslim slave is better than polytheistic men even though he pleases you. They (the polytheists) will bring into the fire (hell) while the God invites to Paradise and forgiveness, with his permission. And God explained the verses (commandments) to mankind that they may take heed (AlBaqara: 221).

\section{Interfaith Marriage in Jews and Christianity}

Interfaith marriage mentioned in Hebrew Scriptures. The Scriptures contain a few cases of interfaith marriages that appear to be approved by God. In Numbers 12:1 "Moses is recorded as having married a nonIsraelite woman who presumably followed a different religion. Aaron and Miriam criticized Moses because of this. God supported Mose's

1998. H. 20. 
decision. He punished Miriam by making her leprous. However, almost all of references to interfaith marriages are condemned. Exodus 34:1216 "Take care not to make a covenant with the inhabitants of the land to which you are going, or it will become a snare among you. You shall tear down their altars, break their pillars, and cut down their sacred poles... You shall not make a covenant with the inhabitants of the land...And you will take wives from among their daughters for your sons, and their daughters who prostitute themselves to their gods will make your sons also prostitute themselves to their gods."

And according to Christian Scriptures; Matthew 1:5 "This passage refers, without comment, to the marriage of Salmon, a Jew, and Rahab, a Canaanite. Their great grandchild was King David. St. Paul makes two negative references to interfaith marriages in two of his Epistles to the Christians at Corinth". 1 Corinthians 7:39 "The wife is bound by the law as long as her husband live; but if her husband be dead, she is at liberty to be married to whom she will; only in the Lord". 2 Corinthians 6:14-15: "Be ye not unequally yoked together with unbelievers: for what fellowship hath righteousness with unrighteousness? And what communion hath light with darkness? And what concord hath Christ with Belial? Or what part hath he that believeth with an infidel?

\section{Marriage According to National Law}

Marriage Law no. 1 said that the definition of marriage is the "inner and outer bond between a man with a woman as husband and wife with the aim to form family (household) on the basis of a happy and eternal divinity of the Almighty. This definition is deeply rooted in the understanding of marriage in Islam. Marriage in Islam is an agreement, transaction, or contract is characterized by the element of Ijab (offer) from the women and Qabul (acceptance) of the men.

Validity of marriage is under the provisions of Marriage Law no. 2, chapter 1 "Marriage is legal if performed according to religions teaching. But, in practice, this provision can only be met when the bride and groom embrace the same religion. However, if they have a different religion, then one must follow another religion. But, in practice the provisions on 
marriage does not accommodate the legitimate marriage between two different faiths or interfaith marriage. Clearly, this is incompatible with the constitution and a number of national laws.

Registration of marriage set out in 2: (1) "marriage is valid if conducted according to the laws of each religion and belief", (2) Every marriage is recorded according to the laws and regulations. Both of chapter legitimate marriage to register. It is meant that the marriage was not recorded by country is illegal. But people generally understand the validity of a marriage, if the married based on religious law, although not listed or registered.

\section{E. Problem of Legal Unification}

According to Islamic law, Muslims are basically prohibited from marriage with other religions. Prohibition of marriage is embodied in consideration of Ulama council, which is forbids marriage with a Muslim and non-Muslim women (including Ahl Kitab). Then, this consideration strengthened again by compilation of Islamic Law (KHI) chapter 40 point $\mathrm{c}$ which states that "prohibited establish a marriage between a man with a non-Muslim woman".

Catholic, in principle, prohibits interfaith marriage, except, in the specific case the bishop may give dispensation to perform interfaith marriages. Protestant allow interfaith marriage if the marriage took place in Protestant churches. Hinduism and Buddhism prohibit interfaith marriage ${ }^{4}$.

In article 8 (f) the Law No. 1/1974 is declared "prohibition of marriage between two people, who have relationships by other applicable laws, forbidden to marry." Under the provisions of this article that in addition there are the prohibitions in the Law No. 1/1974 and other rules, there is also a prohibition that comes from each religion. Thus was very clear that in order to determine whether or not permitted interfaith

${ }^{4}$ Sukarja Ahmad. "Perkawinan Berbeda Agama Menurut Hukum Islam" dalam Problematika Hukum Islam Kontemporer. Jakarta. Pustaka Firdaus. 1994. H. 23. 
marriage depends on the law of religion itself; article 2 (1) JO and Article 8 (f).

\section{F. Interiaith Marriage According to National Law}

Marriage Law does not give an explicit prohibition on marriages by couples who have different religions or beliefs. The marriage law in 1974 produces different interpretations among the public. Some argue that the marriage is invalid because it does not meet both requirements based on religion or based on state law. Meanwhile, on the other hand, there are people who think differently said that the marriage between couples of different religions throughout is based on legitimate religious party.

Marriage Law provides space that can be used as a means to legalize the marriage. Article 56 Marriage Law states that a marriage that took place outside of Indonesia between two Indonesian citizen or a citizen of Indonesia with foreign nationals is valid when performed according to the laws of the country where the marriage took place and, for the citizens of Indonesia does not violate the provisions of Marriage law. After that, mentioned that within 1 year after the husband and wife are returning to the territory of Indonesia, their marriage must be registered at the Registry Office marriage where they lived.

\section{G. Marriage Las as Obstacles of Interiaith Marriage}

After the enactment of Marriage Law No. 1 1974, the arrangements of interfaith marriages seem obstructed by the law itself. Based on the opinion that: First, by remembering the history of marriage law 1973, especially the debate concerning Article 11 paragraph (2) that the "difference due to nationality, ethnicity, nationality, place of origin, religion, belief and descent not a barrier of marriage "and then get a change. So, the interfaith marriage is not possible (forbidden) in Indonesia.

Second, there are several articles which can be used as the basis of the prohibition of interfaith marriage, law No. 1 of 1974 Article 2 paragraph (1) and article 8 (f). In Article 2 paragraph (1) stated, 
"Marriage is a legitimate, if conducted according to the laws of each religion and belief". Then, the explanation stated "With the formulation of article 2, paragraph (1), there is no legal marriage outside our religion or belief, in accordance with the Constitution of 1945 . What we meant by the laws of each religion or belief, including statutory provisions that apply to religious groups and beliefs that do not conflict or not otherwise provided in this law. "

\section{H. Human Right Persiective on Interiaith Marriage in Indonesia}

Marriage should be a social contract between two people with sincerity and responsible and empowered by the state law and according to religious party. The significant problem to understand the marital of interfaith marriage is not about differences in religion, but a matter of state responsibility in protecting and guaranteeing the rights of citizens. So, the problems should be vertical relations in the relationship between state and citizens, not horizontal relationships involving relationships among the citizens and their belief and their interpretations.

It is important because the issue of interfaith marriage Indonesia is a matter of law, while the interpretation of religions on interfaith marriage is a matter of theological and religious interpretations. Indonesia is not a religious state and national law is source of formal law. National law and Marriage Law No. 1 of 1974 based on religious law. But, it tends be tied to the nation's basic philosophy of "Pancasila". That principle recognizes the diversity and plurality of society. It must be the basis of the formation and creation of a law or a law is national.

In the context of nation state, it is forbidden to produce a sectarian law which is only benefits a particular religious group and ignores the voice of other religious communities. Every citizen is guaranteed and has equal rights, no matter what their religions and beliefs. Any consideration and reasons for making regulation or law must base on equality of every citizens without distinction their religions and beliefs. In the perspective of human rights, any regulation or law should consider in advance the 
state obligation to promote, protect and to fulfill the fundamental rights of citizens.

\section{Conclusion}

Marriage Law looked at marriage is not only seen from the purely formal aspect, but also from the aspect of religion. Aspects of religion set about the validity of a marriage, while the formal aspects set about the administrative aspects or marriage documentation. Basically, Muslims are prohibited from marriage with other religions. Prohibition of marriage is embodied in consideration of Ulama council, which is forbids marriage with a Muslim and non-Muslim women (including Ahl Kitab). But in National Law mentioned that marriage Law does not give an explicit prohibition on marriages by couples who have different religions or beliefs. The marriage law in 1974 produces different interpretations among the public.

\section{Reierrence}

Ahmad, Sukarja. "Perkawinan Berbeda Agama Menurut Hukum Islam" dalam Problematika Hukum Islam Kontemporer. Jakarta. Pustaka Firdaus. 1994.

Galib, Muhammad. Ahl Kitab; Makna dan Cakupannya. Jakarta. Paramadina. 1998.

Hamidi, Jazim, dan Husnu Abadi. Intervensi Negara Terhadap Agama. Yogyakarta. UII Press. 2001.

Helmi, Muhammad Ishar. "Penerapan Azas Equality Before The Law dalam Sistem Peradilan Militer", Jurnal Cita Hukum, Vol. 1, No. 2. Desember 2013.

Idris, Irfan. Islam, Konstitusionalisme, dan Pluralisme. Yogyakarta. IRCHiSoD, 2009.

Jones, Gavin W, Chee Heng Leng, Maznah Muhammad, erc,. Muslimnon-Muslim Marriage; Political and Cultural Contestation in Southeast Asia, Singapura, ISEAS Publishing. 2009. 
Mardani. Hukum Acara Perdata Peradilan Agama dan Mahkamah Syariah. Sinar Grafika. 2009.

Mulia, Siti Musda. Islam dan Inspirasi Kesetaraan Gender. Kibar Press Yogyakarta. 2007.

Rasyidi, M. Kasus RUU Perkawinan dalam Hubungan Islam dan Kristen. Bulan Bintang Jakarta. 1974. 